\title{
Performance of Self Compacting Concrete Replaced with Saturated Recycled Aggregate
}

\author{
Vivek K. Viswanath, Vilas Sankar K. P., Abhilasha P. S., M. Alosta
}

\begin{abstract}
The use of recycled aggregate in any concrete saves the virgin coarse and fine aggregates to create for the production of concrete. This concept will deliver an ecofriendly, reduced eviction of natural resources and produce a green concrete concept. Coarse aggregate consists of more than $60 \%$ of total volume in ordinary concrete but only $40 \%$ is required for Self Compacting Concrete (SCC) by weight. Demolished concrete wastes which are crushed and sieved to the size are used as substitute for natural coarse aggregates. In this paper natural coarse aggregate in self-compacting concrete is replaced with $10 \%, 20 \%, 30 \%, 40 \%, 50 \%, 60 \%, 70 \%, 80 \%, 90 \% \& 100 \%$ recycled aggregates in mix design. Furthermore, a detailed study on workability and hardened properties of specially proportioned mixes are also carried out and satisfactory results are obtained. Thus the derived SCC can come up with reduced $\mathrm{CO}_{2}$ emissions, economical and energy saving with all additional well-known advantages of fluid concrete.
\end{abstract}

Keywords: Recycled aggregate (RCA), Self-compacting concrete (SCC), Slump flow, Super plasticizer.

\section{INTRODUCTION}

Self-compacting concrete is a somewhat newly invented concrete that will have the following advantages over normally vibrated concrete. It will flow by its own weight without any compaction and completely fills the mould even in congested reinforcement joints. Its high fluidity and segregation resistance offers a very high homogeneity, less voids, superior level finishing and durability. One of the primary challenges encountered by civil engineering industry is to accomplishing the work ecofriendly aspects. In this recent era, the construction industry has grown tremendously and produce a huge amount of wastes. These wastes compose of considerably large portion of total solid waste production in the globe. Most of these are used as land fill. As a result of the lack of dumping sites and increased cost of transportation, most of the countries are encountering problems in managing and disposing of such wastes. It has been reported that the international concrete industry consumes nearly a 10 billion

Revised Manuscript Received on August 15, 2020.

* Correspondence Author

Vivek K *, P.G scholar, Department of Civil Engineering, Vidya Academy of Science and Technology, Thrissur, Kerala, India. E-mail: vivekkv2013@gmail.com.

Vilas Sankar K. P. Lecturer, Department of Civil Engineering, University of Nizwa, Oman. E-mail: vilas@unizwa.edu.om.

Abhilasha P. S. Associate Professor, Department of Civil Engineering Vidya Academy of Science and Technology, Thrissur. E-mail: abhilasha@vidyaacademy.ac.in

M. Alosta, Laboratory Instructor, University of Nizwa, Oman.

(c) The Authors. Published by Blue Eyes Intelligence Engineering and Sciences Publication (BEIESP). This is an open access article under the CC BY-NC-ND license (http://creativecommons.org/licenses/by-nc-nd/4.0/)

tonnes of coarse aggregate and produces past 1 billion tonnes of construction and demolition waste each year [1]. All these aspects promote the beneficial reuse of the produced wastes for efficient utilization and save environment. So, the utilization of demolished concrete waste and recycled aggregate crushed into the size of coarse aggregate can yield significant environmental impact [2]. Application of RCA in self-compacting concrete with varying percentages of RCA from $10 \%$ up to $100 \%$ is examined. Fresh properties are studied by conducting tests such as slump flow test, $T_{500}$ test, V-funnel test, L-box test in laboratory according to European guidelines (EFNARC)[6]. Hardened properties of all the replaced mixes are studied and compared with control SCC specimen.

\section{SCOPE OF THE WORK}

Characteristic strength of concrete is $35 \mathrm{~N} / \mathrm{mm}^{2}$ designated as $\mathrm{M}_{35}$ grade is designed. Cement is replaced with $30 \%$ of fly ash in all the mixes.

\section{REVIEW CRITERIA}

\section{A. Cement}

Ordinary Portland Cement of 53grade is adopted in this work. It is dark grey in colour and conforms to IS 12269-2013. The physical properties of the cement are presented in Table I.

\section{B. Fly Ash}

It is a material which solidifies while suspended in exhaust gases and is collected by electrostatic precipitator. They are commonly spherical in shape and range from $0.5 \mu \mathrm{m}$ to 300 $\mu \mathrm{m}$. Due to the unavailability of class $\mathrm{C}$ fly ash, class F fly ash is used. It is attained by burning of harder older, anthracite \& bituminous coal. It is pozzolanic in nature and consist of less than $0.7 \%$ lime. The properties are shown in Table I.

Table- I: Properties of Binder Materials

\begin{tabular}{|c|c|c|}
\hline Properties & Cement & Fly Ash \\
\hline Fineness & $5 \%$ & $19 \%$ \\
\hline Specific gravity & 3.14 & 2.62 \\
\hline Consistency & $34 \%$ & $29 \%$ \\
\hline Initial setting time & $1 \mathrm{hr}$ & $1.15 \mathrm{hrs}$ \\
\hline Final setting time & $4 \mathrm{hrs}$ & $5 \mathrm{hrs}$ \\
\hline
\end{tabular}

\section{Fine aggregate}

Due to the unavailability of natural river sand, locally available rock sand conforming to grading zone II is used.

\section{Coarse aggregate}

Waste concrete cubes available in the material testing

Published By:

Blue Eyes Intelligence Engineering and Sciences Publication

(C) Copyright: All rights reserved.

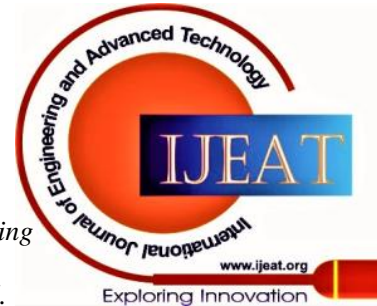




\section{Performance of Self Compacting Concrete Replaced with Saturated Recycled Aggregate}

laboratory are crushed and sieved to the size of 10-12.5 mm as coarse aggregate. The properties of aggregates are shown in Table II.

\section{E. Recycled aggregate}

Waste concrete cubes available in the material testing laboratory are crushed and sieved to the size of 10-12.5 mm and are used as recycled aggregate. It is saturated and further surface-dried to compensate the strength reduction due to the higher water absorption of RCA. Fig. 1 shows the micro structure of the recycled aggregate.

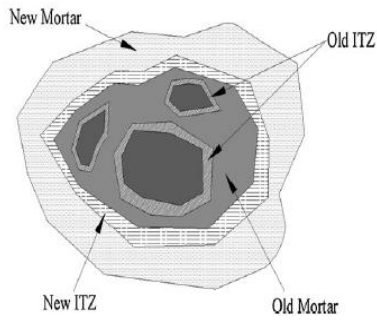

Fig. 1. Structure of recycled aggregate

Table- II: Properties of aggregates

\begin{tabular}{|c|c|c|c|}
\hline Properties & FA & CA & RCA \\
\hline $\begin{array}{c}\text { Bulk density compact } \\
\left(\mathrm{kg} / \mathrm{m}^{3}\right)\end{array}$ & 1756.7 & 1513.5 & 1460 \\
\hline Fineness modulus & 2.82 & 7.07 & 8.68 \\
\hline Void ratio(compact) & 0.407 & 0.81 & 0.80 \\
\hline Specific gravity & 2.5 & 2.82 & 2.61 \\
\hline $\begin{array}{c}\text { Water absorption } \\
\text { Aggregate crushing value }\end{array}$ & --- & 23.85 & 26.33 \\
\hline
\end{tabular}

\section{F. Super Plasticizer}

High performance super plasticizer based on Poly Carboxylic Ether (PCE) having trade name Master Glenium 8233 is used as chemical admixture. It is free from chloride ion of low alkali content and is compactable with all types of cements. It is blended with Viscosity Modifying Agent (VMA) and belongs to ASTM C494 type F and IS 2645-2003. After trial and error optimum percentage is adopted as $0.9 \%$. The chemical properties of SP is exhibited in Table III.

Table- III: Chemical properties of Super Plasticizer

\begin{tabular}{|l|l|}
\hline Aspect & Light brown liquid \\
\hline Relative density & $1.08 \pm 0.01 @ 25^{\circ} \mathrm{C}$ \\
\hline pH & $>=6$ \\
\hline Chloride ion & $0.2 \%$ \\
\hline
\end{tabular}

\section{G. Water}

Ordinary fresh tap water is used in the entire work.

\section{MIX DESIGN}

Mix design is carried out to have a mix of $\mathrm{M}_{35}$ grade and a target mean strength of $43.25 \mathrm{MPa}$ and water binder ratio is fixed as 0.33 . A microsoft spread sheet is specially prepared for the mix design with reference to Krishnamurthy et al. 2012 [4]. Steps adopted are as follows;
- Assume air content by percentage of concrete volume.

- Input coarse aggregate blending by percentage weight of total CA

- Input percentage of CA in dry state to calculate the CA volume in the concrete volume.

- Adjust percentage of FA volume in mortar volume.

- Obtain required paste volume. Adopt suitable water binder ratio by weight.

- Input percentages of fly ash by weight of cementitious material.

- Input the dosage of SP cum retarder by percentage weight of binder.

- Adjust the binder (cementitious material) content by weight to obtain the required paste.

Table- IV: Main input parameters

\begin{tabular}{|c|c|}
\hline Dry density of CA (kg/cum) & 1513.5 \\
\hline \% of CA in dry state & $50 \%$ \\
\hline Dry density of sand (kg/cum) & 1756.7 \\
\hline \% of sand in mortar & $43 \%$ \\
\hline \% of fly ash(\% Wt of binder) & $30 \%$ \\
\hline \% of RCA(\% Wt of CA) & $0-100 \%$ \\
\hline Water binder ratio & 0.33 \\
\hline Binder content & 540 \\
\hline SP dosage (\% Wt of binder) & $0.9 \%$ \\
\hline
\end{tabular}

(CA- coarse aggregate, RCA- recycled coarse aggregate, SP- super plasticizer)

Table-V: Output parameters

\begin{tabular}{|c|c|}
\hline & Lit/cum \\
\hline CA Volume & 268.35106 \\
\hline Mortar Volume & 731.64894 \\
\hline FA Volume & 314.60904 \\
\hline Paste Volume & 394.7 \\
\hline Cement Volume & 120 \\
\hline Volume of Water & 178.2 \\
\hline Volume of Fly Ash & 72 \\
\hline Volume of SP & 4.5 \\
\hline Volume of VMA & 0 \\
\hline
\end{tabular}

Table- VI: Design mix obtained

\begin{tabular}{|c|c|c|c|c|}
\hline C & FLA & FA & CA & Water \\
\hline 1 & 0.407 & 1.979 & 1.904 & ---- \\
\hline 397.37 & 162 & 786.5 & 756.7 & 184.5 \\
\hline
\end{tabular}

By trial and error method, the optimum dosage of superplasticizer is found out as $0.9 \%$ with water powder ratio 0.33 . The Table IV, V and VI shows the input parameters, output parameters and the final mix proportions.

Published By:

Blue Eyes Intelligence Engineering and Sciences Publication

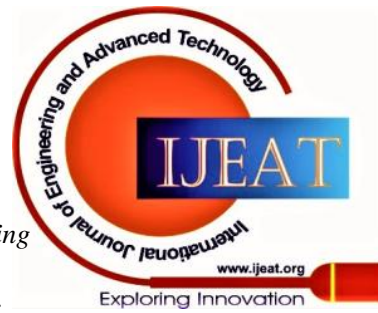




\section{EXPERIMENTAL PROGRAM}

\section{A. Fresh Concrete Properties}

\section{Slump flow test}

Slump flow test combined with $\mathrm{T}_{500}$ time investigation helps to estimate the flow rate plus the flow-ability of self-consolidated concrete along with intrusion unavailability. The standard values of slump test results are depicted in EN 12350-2. The experiment set up is shown in Fig. 2. The end result of the experiment is a verification on the filling ability of self-compacting concrete. In order to start the above test, the steel base place is cleaned and wiped with oil, and make sure that it is free from every impurities and dust. Now hold the slump cone in inverted position, i.e. $100 \mathrm{~mm}$ top circle should be at the bottom of the cleaned base plate. Hold the slump cone in stable position by making it pure vertical guaranteeing that the flowing concrete will not escape through the bottom circle. Pour the flowing concrete from the top until it fill the cone without any compaction and disturbance. the excess concrete at the top of the cone can be struck off. Don't allow the filled cone to stand more than 30 secs meanwhile clear out any spillage of concrete near the base plate and confirm that there is no excess water spillage from the bottom of the cone. Drive up the cone vertically in a single movement and at the same time launch the stopwatch countdown instantly during the lifting up of the cone. Record the time taken by the flowing concrete to reach $500 \mathrm{~mm}$ circle diameter drawn point with an accuracy of 0.1 secs. Further, $\mathrm{T}_{500}$ time gives an indication of the speed of the flow and by that viscosity of the moving concrete also be monitored. Additionally, it studies the maximum flow diameter of the sample.

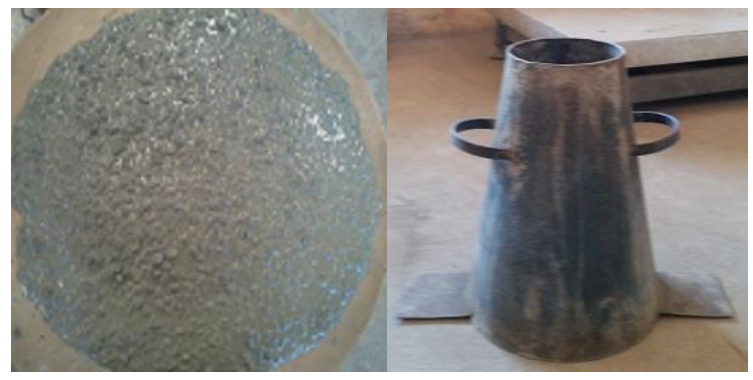

Fig. 2. Slump flow test and apparatus

\section{V-funnel test}

The viscosity and the filling ability of SCC can be investigated by $\mathrm{V}$ Funnel test shown in Fig. 3. Before performing the test, the interior surface of the funnel set up and its gate opening must be washed, dried and oiled properly. Later shut the gates of the funnel setup and introduce the concrete specimen into the funnel by complete avoidance external disturbance or any rodding compaction. The top excess level of concrete specimen inside the funnel can be levelled off using a trowel. Place a container to collect the flowing concrete which reach the bottom of the funnel after holding the specimen for $(10 \pm 2) \mathrm{s}$ inside the funnel. Following that, open the gate and record the time $t_{v}$, which is the V-funnel flow time.
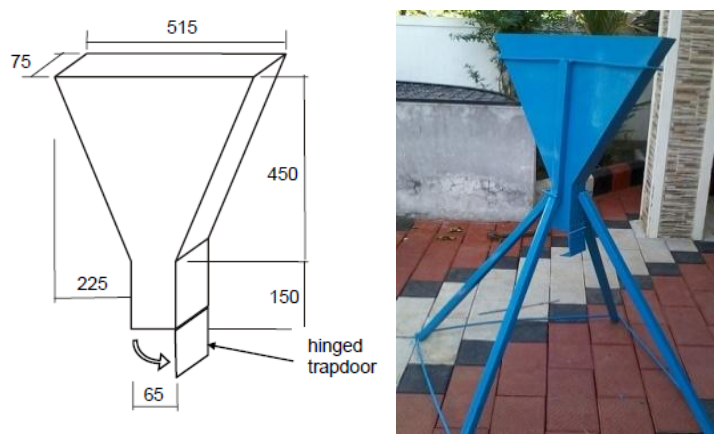

Fig. 3. V-Funnel apparatus

\section{L-Box test}

The intention of L-Box test is to observe the passing ability of SCC. It demonstrates the ability of the specimen to flow through narrow gap of reinforcement bars inside the structural elements. In this study, three bar test variation has been done since it gives more realistic site situation than two bar variation test inside the L-box. Place the L-box apparatus on a level surface and close the gate placed at the junction of horizontal and vertical chambers of the apparatus. Transfer the specimen concrete to the vertical section of the L-Box by allowing the specimen to stay for $(60 \pm 10)$ secs. Observe any clogging or segregation during the flow inside the chambers after the gate opening. At the end of flow movement, checkout the vertical distance from the top layer of concrete sample to the top level of the horizontal chamber section as depicted in Fig. 4 and Fig. 6. This height verification can be done in three equally apart points through the width of the L-box horizontal chamber and calculate the mean depth of the sample $\mathrm{H}_{2} \mathrm{~mm}$. The same method can be followed to calculate the $\mathrm{H}_{1} \mathrm{~mm}$ at the opposite side of the $\mathrm{L}$ box horizontal chamber.

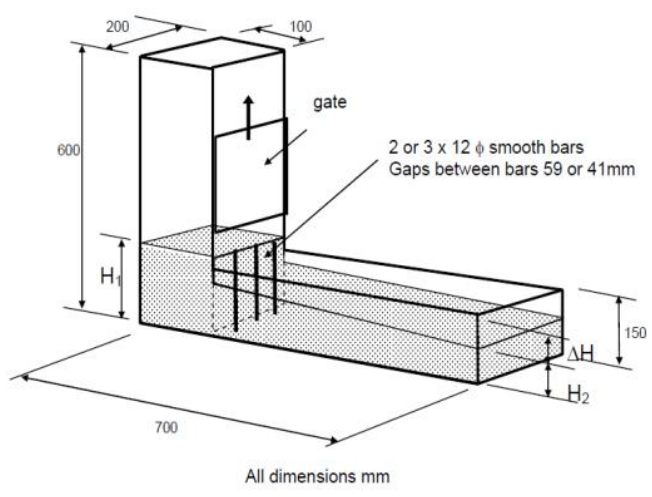

Fig. 4. L-Box apparatus

The fresh properties of the different trial and error mix design are presented in Table VII.

\section{B. Hardened Concrete Properties}

Cubes, cylinders and prisms are casted to study the strength property of each replaced mixes. All the specimens are cured by immersing in water. Cubes and cylinders are tested after 7,14 \& 28 days of water curing in universal testing machine. The samples are shown in Fig. 5.

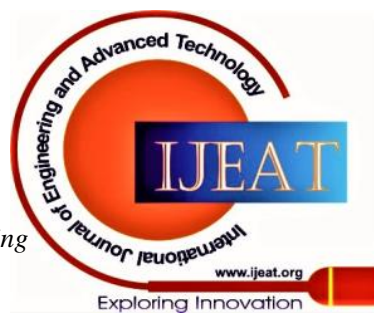




\section{Performance of Self Compacting Concrete Replaced with Saturated Recycled Aggregate}

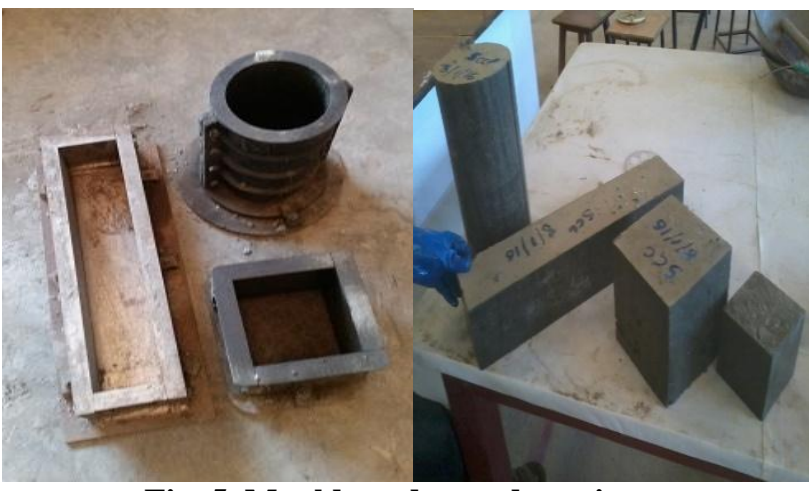

Fig. 5. Moulds and casted specimen

Table-VII: Fresh Properties of design mixes

\begin{tabular}{|c|c|c|c|c|}
\hline Designation & $\begin{array}{c}\text { Slump } \\
\text { flow } \\
\text { diameter } \\
\text { (mm) }\end{array}$ & $\begin{array}{c}\text { V-funnel } \\
\text { time(s) }\end{array}$ & $\mathbf{T}_{500 \text { (s) }}$ & $\begin{array}{c}\text { Passability } \\
\left.\mathbf{( H}_{\mathbf{1}} / \mathbf{H}_{\mathbf{2}}\right)\end{array}$ \\
\hline R0 & 730 & 15 & 3 & 0.98 \\
\hline R10 & 720 & 18 & 5 & 0.97 \\
\hline R20 & 716 & 19.5 & 6.5 & 0.95 \\
\hline R30 & 712 & 21 & 7 & 0.94 \\
\hline R40 & 710.5 & 21.8 & 8 & 0.936 \\
\hline R50 & 708 & 22.4 & 9.5 & 0.92 \\
\hline R60 & 705.4 & 23.1 & 10.2 & 0.9 \\
\hline R70 & 700 & 24 & 10.7 & 0.89 \\
\hline R80 & 694 & 25.1 & 11 & 0.87 \\
\hline R90 & 690 & 26 & 11.9 & 0.85 \\
\hline R100 & 685 & 26.6 & 12.6 & 0.84 \\
\hline
\end{tabular}

\section{RESULTS AND DISCUSSIONS}

\section{A. Fresh concrete properties}

\section{Slump flow diameter}

Slump flow diameter variation are presented in Fig. 7. It shows an inverse relationship with percentage of RCA. It is as the result of the adhered mortar and higher water absorption of RCA. Initial stages of replacement show percentage variation are about $1.36 \%$ with $\mathrm{R}_{0}$ and the variation increases as the replacement ratio increases. Finally, it reaches about $6.16 \%$ for $100 \%$ replacement. Angular shape and rough nature of RCA reduces the flow.

$\mathrm{T}_{500}$ time also shows the same behaviour as explained.

\section{V-Funnel time}

The variation of V-funnel time with percentage increase of RCA is shown in Fig. 8. As the percentage of replacement increases V-funnel time increases. V-funnel time is an indication of viscosity of the mix. So, the results show that increase in the RCA makes the mix more viscous. This is because of the same reason which reduces flow diameter. The roughness of RCA causes resistance to flow through v-funnel. Viscosity can be reduced by higher dosage of super plasticizer. According to EFNARC guidelines all the mixes belongs to VF-2.

\section{Passability}

Passing ability is the rate of height from concrete by the horizontal section from the box. Increased percentages show an inverse relationship with passability. It goes on decreasing from 0.98 to 0.84 as the percentage of replacement increases to $100 \%$. This indicates that as the RCA content increases flow through congested reinforcement delays. The variations are shown in Fig. 9. All the replaced mixes show reduced workability properties in all aspects. Workability properties can be improved by increasing dosage of super plasticizer. It should be checked that any kind of segregation or bleeding is happening at any time.

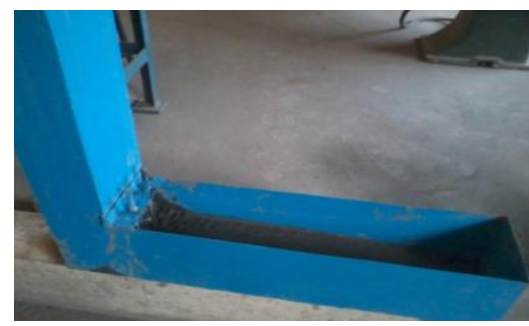

Fig 6. Concrete flows through L- box

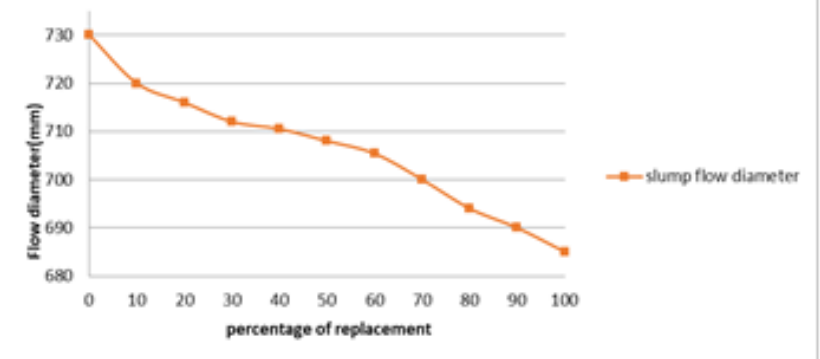

Fig. 7. Slump flow diameter variations

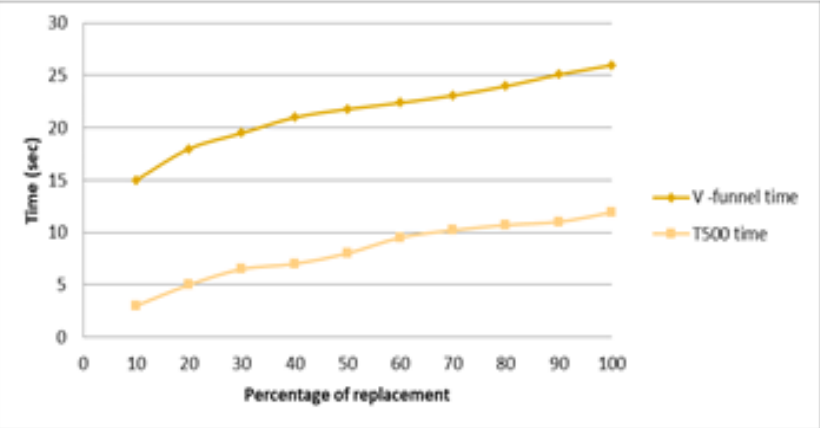

Fig. 8. Variation of $V$-funnel time and $T_{500}$ time with $\%$ of replacement

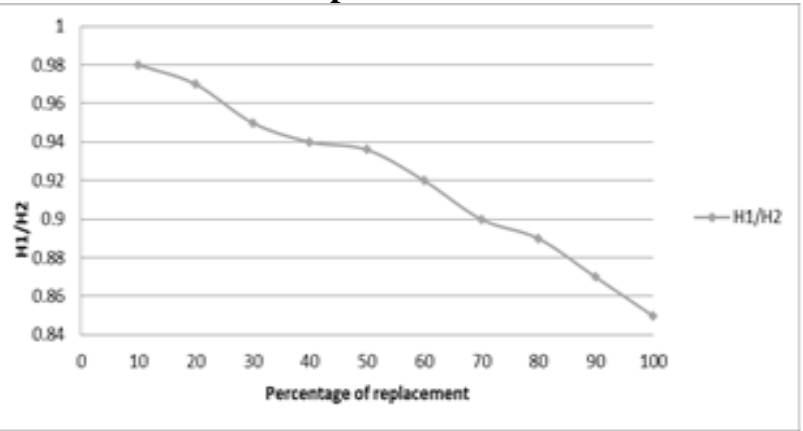

Fig. 9. Variation of the ratio $\mathrm{H}_{1} / \mathrm{H}_{2}$ with $\%$ of replacement

Published By:

Blue Eyes Intelligence Engineering

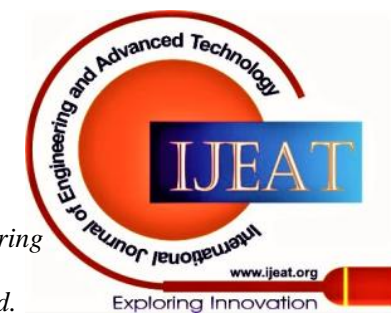


Table- VIII: Typical range of values of workability

\begin{tabular}{|c|c|c|c|c|}
\hline No: & Method & Unit & \multicolumn{2}{|c|}{$\begin{array}{c}\text { Typical range of } \\
\text { values }\end{array}$} \\
\cline { 4 - 5 } & & & minimum & Maximum \\
\hline 1 & Slump flow test & $\mathrm{mm}$ & 550 & 850 \\
\hline 2 & $\mathrm{~T} 500$ slump flow & $\mathrm{mm}$ & 2 & 10 \\
\hline 3 & V - funnel time & $\mathrm{sec}$ & 9 & 25 \\
\hline 4 & L - box test & $\mathrm{H}_{2} / \mathrm{H}_{1}$ & 0.8 & 1 \\
\hline
\end{tabular}

\section{B. Hardened concrete properties}

\section{Compressive strength}

All the mixes are designed to get target strength of 43.25 MPa. Characteristic strength of the mix is $35 \mathrm{MPa}$ and all the mixes achieved this value. As the percentage of RCA increases, 28-day compressive strength of mixes show declining nature. The 7- and 14-days compressive strength shows that the replaced mixes attain early strength than normal mix. This is because of the adhered cement mortar on the RCA which accelerates the hydration process. The difference in compressive strength during the replacements of RCA is depicted graphically in Fig. 10.

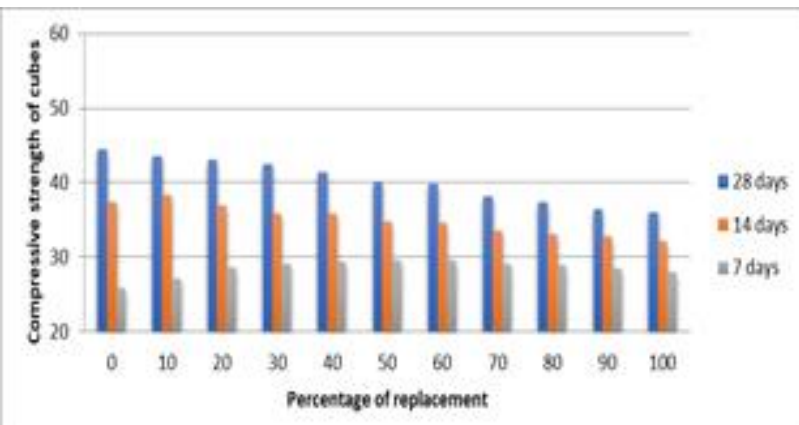

Fig. 10. Compressive strength v/s \% of replacement

2. Split tensile strength

By comparing the results of $7^{\text {th }}$ day strength, it is obvious that the tensile strength increases gradually as the percentage of replacement increases. This is because of the early strength gain property of RCA. The same trend can be visible in the 14 days strength results but rate of increase with percentage of replacement is less compared to $7^{\text {th }}$ day results. Comparing $7^{\text {th }}$ day and $28^{\text {th }}$ day results of each mix about $30 \%$ strength is only achieved on 7-day curing for control mix. But in the case of R100 mix about $76 \%$ strength is attained in $7^{\text {th }}$ day. This percentage growth of strength shows an increase for all mixes, as the \% of replacement increases. The split tensile strength variation trends are shown in Fig. 11.

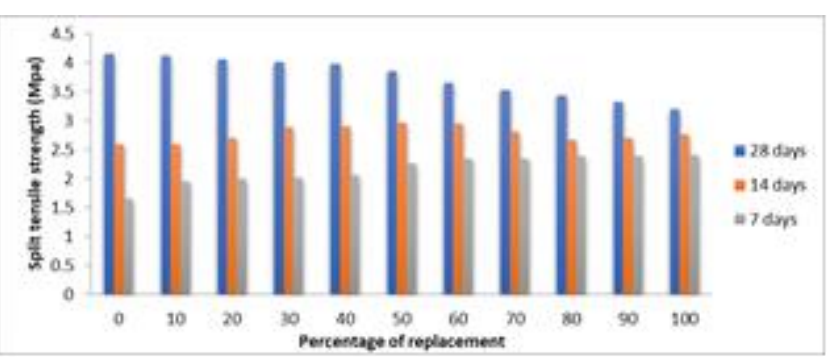

Fig. 11. Split tensile strength v/s percentage of replacement

\section{Flexural strength}

The flexural strength also shows the same trend as the other hardened properties. It is very evident that the adhered mortar on RCA not only reduces workability but also reduces hardened concrete properties too. The flexural strength variations are shown in Fig. 12. The hardened properties of the SCC are combined in Table IX.

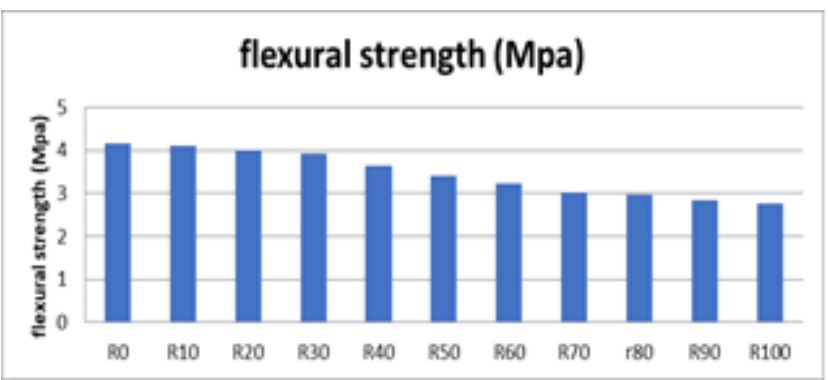

Fig. 12. Variation of flexural strength (MPa)

Table- IX: Compressive, tensile and flexural strength results

\begin{tabular}{|c|c|c|c|c|c|c|c|}
\hline \multirow{2}{*}{$\begin{array}{c}\text { Days of } \\
\text { curing }\end{array}$} & \multicolumn{2}{|c|}{$\mathbf{7}$ days } & \multicolumn{2}{c|}{14 days } & \multicolumn{3}{c|}{ 28 days } \\
\cline { 2 - 8 } & Cube & Cylinder & Cube & Cylinder & Cube & Cylinder & Prism \\
\hline R0 & 25.77 & 1.65 & 37.3 & 2.59 & 44.49 & 4.15 & 4.16 \\
\hline R10 & 28.44 & 1.95 & 38.66 & 2.59 & 43.5 & 4.12 & 4.11 \\
\hline R20 & 28.71 & 1.99 & 36.9 & 2.69 & 43.01 & 4.05 & 4.01 \\
\hline R30 & 29.33 & 2.01 & 35.9 & 2.89 & 42.4 & 4.01 & 3.92 \\
\hline R40 & 29.35 & 2.05 & 35.87 & 3 & 41.38 & 3.98 & 3.65 \\
\hline R50 & 29.5 & 2.26 & 34.69 & 2.96 & 40.21 & 3.85 & 3.42 \\
\hline R60 & 29.53 & 2.33 & 34.83 & 2.95 & 39.8 & 3.65 & 3.24 \\
\hline R70 & 29.8 & 2.34 & 33.56 & 2.85 & 38.2 & 3.53 & 3.03 \\
\hline R80 & 30 & 2.38 & 33.05 & 2.55 & 37.35 & 3.43 & 2.98 \\
\hline R90 & 29.9 & 2.39 & 32.8 & 2.62 & 36.5 & 3.32 & 2.85 \\
\hline R100 & 29.95 & 2.4 & 32.1 & 2.56 & 36.01 & 3.19 & 2.76 \\
\hline
\end{tabular}

\section{CONCLUSION}

- Recycled aggregates can be considered as a good substitute to natural aggregates even in self-compacting concrete.

- A successful mix design for SCC with recycled aggregate was developed confirming to EFRNARC specifications by trial and error method.

- An increase of $19.70 \%$ slump variation was observed with $100 \%$ recycled aggregate replacement when compared with minimum slump requirement based on standard guidelines.

- The V-funnel test which is an indication towards viscosity necessity in SCC falls well in the range of 9-25 sec specified by the EFNARC guidelines for all percentage replacements of recycled aggregates.

- $\mathrm{T}_{500}$ results arrived well in the field of standard guideline proving that recycled aggregate is a substitute for natural aggregate in SCC.

- In every sets of replacement of recycled aggregate, the recommended passing ratio value of 0.80 were passed.

- The hardened properties results of every recycled aggregate SCC mixes pop up within the acceptable limits prescribed in the standard code.

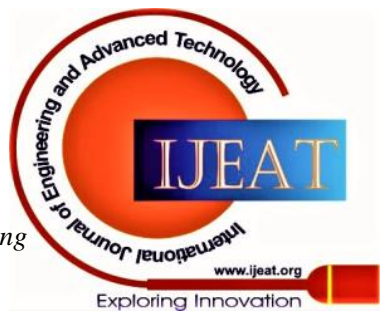




\section{REFERENCES}

1. Mehta, P. K., "Concrete Technology at the Crossroads - Problems and Opportunities," Concrete Technology: Past, Present, and Future, SP 144 American Concrete Institute, Farmington Hills, Mich., 1993, pp.1-31

2. Wai H.K., Mahyuddin R., Kenn J.K. and Zailan S., "Influence of the amount of recycled coarse aggregate in concrete design and durability properties", Construction and Building Materials, 2012, pp 565-573.

3. Valeria C., Giacomo M., "Influence of mineral additions on the performance of $100 \%$ recycled aggregate concrete, Construction and Building Materials", 2009, pp 2869- 2876.

4. Krishna Murthy, N., A.V. Narasimha Rao, I. V. Ramana Reddy, M. Vijaya Sekhar Reddy, Mix Design Procedure for Self Compacting Concrete, International Journal Organization of Scientific Research (IOSR) (IOSR), Volume 2, Issue 9, (September-2012), pp. 33-41.

5. "Recycled aggregates for Concrete", ICJ Editorial,2009, pp 3-4.

6. Okamura, H. and M. Ouchi, "Self-compacting increased the V-funnel time. Concrete", Journal of Advanced Concrete Technology,2003.

7. Safiuddin, M.D., M.A. Salam and M.Z. Jumaat, "Effects of recycled concrete aggregate on the fresh properties of self-consolidating concrete", CIVIL and Mechanical Engineering, XI(4).

8. EFNARC, "Specification and guidelines for self-compacting concrete. European Federation of Producers and Applicators of Specialist Products for Structures", 2005

9. Okamura H, Ozawa K., "Mix design for self-compacting concrete". Concrete Library of Japanese Society of Civil Engineers 1995, 25(6):107-120.

10. ACI, "Building Code Requirements for Structural Concrete" (ACI 318-02) and Commentary.

11. ACI 318R-02)", ACI Standard, American Concrete Institute, Farmington Hills, U.S.

\section{AUTHORS PROFILE}

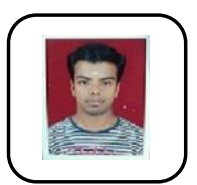

Vivek K Viswanath has completed his M. Tech in Structural Engineering in the year 2016.

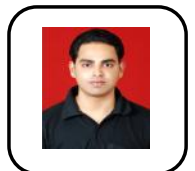

Vilas Sankar K.P. is presently working as Lecturer in University of Nizwa, Oman has completed his M. Tech in 2008. He has 13 years of experience in academics and 3 publications in various journals.

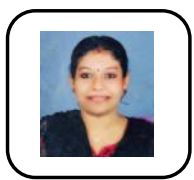

Abhilasha P. S has completed her M. Tech. in Computer Aided Structural Analysis and Design in the year 2004 from CUSAT and currently pursuing her Ph.D. at Karunya University. She has two years of experience in the Industry and 15 years of experience in academics. She has 11 publications in various journals and presented papers in eight conferences at International and National levels.

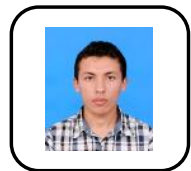

M. Alosta is presently working as laboratory instructor in University of Nizwa, Oman has completed his Master in 2019. 